\title{
ESEJI
}

Dr JELENA Đ. LOPIČIĆ JANČIĆ

Beograd, Bulevar Mihaila Pupina 7

\section{ZAKON O REHABILITACIJI REPUBLIKE SRBIJE U PRAKSI}

\begin{abstract}
APSTRAKT: $U$ članku se razmatraju institut rehabilitacije i zakon 0 rehabilitaciji Republike Srbije od 2006. i 2011. Prikazani su opšti institut rehabilitacije kao i primena zakona o rehabilitaciji Republike Srbije u praksi. Posebno je obrađen sudski slučaj rehabilitacije kneza Pavla Karađorđevića, koji je rehabilitovan 28. novembra 2011.
\end{abstract}

Ključne reči: rehabilitacija, krivični postupak, knez Pavle Karađorđević, politička osuđena lica

Poslednjih decenija u Srbiji se dosta pisalo i govorilo o rehabilitaciji uopšte, ali se pre svega mislilo na rehabilitaciju političkih lica koja su osuđena u periodu posle 1944-1945. pa sve do 2000. u tadašnjoj Jugoslaviji. Relativno veliki broj lica je bio osuđen zbog raznih krivičnih dela, političkih krivičnih dela na veće ili manje kazne zatvora, gubitak građanskih prava i konfiskaciju celokupne imovine. U navedenom periodu po tadašnjem Zakonu o krivičnom postupku za pokretanje postupka rehabilitacije osuđenog lica pre 1954. bilo je potrebna saglasnost javnog tužioca, što se u praksi veoma retko dešavalo.

U krivičnom pravu institut rehabilitacije znači omogućavanje osuđenim licima da posle izdržane kazne mogu uživati i sticati sva prava kao i drugi punopravni građani. Cilj rehabilitacije jeste da se osuđenom licu otklone sva ranija ograničenja koja su postojala na osnovu sudske presude i da se ranije osuđeno lice putem resocijalizacije vrati u normalan život kao punopravan i ravnopravan član društva kao i ostali građani. Na ovaj način rehabilitovano lice dobija status neosuđivanog lica. Rehabilitacija može biti zakonska i sudska. Zakonska rehabilitacija nastupa samo na osnovu zakona i to samo za lakša krivična dela, dok sudska rehabilitacija nastaje na osnovu sudske odluke. ${ }^{1}$

${ }^{1}$ Dušan Jakovljević, Rehabilitacija u krivičnom pravu, Beograd 1981, 40-43; Zoran Stojanović, Krivično pravo opšti deo, XIV izdanje, Beograd 2007, 331-334; Bogdan Zlatarić, Rehabilitacija i 
Sa pravnog aspekta je neshvatljivo da je za pokretanje postupka rehabilitacije osuđenog lica po Zakoniku o krivičnom postupku tražena saglasnost javnog tužioca. U mnogim evropskim državama za pokretanje rehabilitacije osuđenog lica ne postoje prethodni uslovi. Navodimo primer rehabilitacije lica koja su bila osuđena pre nekoliko vekova kao Đordano Bruno (1548-1600), Galileo Galilej (1564-1642), a rehabilitovana tek u XX veku.

Svakako da se postavlja pitanje zašto je postojala prepreka u tadašnjem Zakoniku o krivičnom postupku za rehabilitaciju ranije osuđenih lica pre 1954. Teško je dati odgovor na ovo pitanje, jer u postojećoj krivičnopravnoj literaturi ovo pitanje nije razmatrano. Čak se i u komentarima Zakonika o krivičnom postupku nije komentarisao član koji je predviđao saglasnost javnog tužioca. Ovu pojavu treba posmatrati u kontekstu tog vremena, gde o određenim pravnim rešenjima koja su očigledno bila političke, a ne pravne prirode ne treba pisati i diskutovati. Zakonodavci su verovatno uvideli da je relativno veliki broj lica neopravdano osuđen zbog političkih krivičnih dela, da bi njihova rehabilitacija u redovnom krivičnom sudskom postupku uspela i da bi to bila teška kompromitacija ne samo pravosuđa nego i države. Usled proteka vremena od više decenija pitanje rehabilitacije se praktično nije spominjalo sve do devedesetih godina XX veka, niti je bilo više takvih slučajeva osim možda neznatan broj pojedinačnih. Ta osuđena lica kao i njihovi potomci su uvideli da praktično ne postoje realne zakonske mogućnosti za pokretanje i vođenje postupka rehabilitacije u krivičnom sudskom postupku. Rehabilitacija osuđenih lica za obična krivična dela takođe je u retkim slučajevima bila sprovedena obnovom krivičnog postupka, gde se naknadno utvrdilo da osuđeni nije izvršio krivično delo za koje je osuđen nego je u međuvremenu pronađen pravi izvršilac tog dela.

U posleratnoj jugoslovenskoj praksi, kao što smo naveli, do kraja $\mathrm{XX}$ veka sudske rehabilitacije su bile veoma retke. Jedna sudska rehabilitacija je ipak ostala zapamćena, a bila je vezana za suđenje pukovniku srpske vojske Dragutinu Dimitrijeviću Apisu (1876-1917) i grupi srpskih oficira zbog navodne zavere, pobune $\mathrm{u}$ vojsci i priprema atentata na prestolonaslednika Aleksandra Karađorđevića, koje je održano 1917. u Solunu. Revizijom Solunskog suđenja koje je izvršeno 1953. pred Vrhovnim sudom Srbije u Beogradu, rehabilitovani su Dragutin Dimitrijević Apis i sva osuđena lica. Utvrđeno je da su čitava optužba kao i suđenje bili inscenirani i svi osuđeni su oslobođeni i rehabilitovani. ${ }^{2}$

pravne posledice osude, Zbornik Pravnog fakulteta u Zagrebu, br. 1-2, Zagreb 1960, 46; Nikola Srzentić, Aleksandar Stajić, Ljubiša Lazarević, Krivično pravo SFRJ, Opšti deo, Beograd 1978, 535.

${ }^{2}$ Borivoje Nešković, Istina o Solunskom procesu, Beograd 1953; Milan Ž. Živanović, Solunski proces hiljadu devesto sedamnaeste, Beograd 1955; Dejvid Mekenzi, Apis, Gornji Milanovac 1989; Dejvid Mekenzi, Solunski proces, Beograd 1998. 
Posle Drugog svetskog rata nova komunistička vlast je na osnovu tzv. revolucionarne pravde lišila života i slobode veliki broj lica iz političkih, verskih, nacionalnih ili ideoloških razloga. Karakteristika ovih sudskih odluka ili odluka bez ikakvih drugih rešenja nekog nadležnog organa bila je konfiskacija nepokretne i pokretne imovine. Broj tih lica nije utvrđen, ali razni autori navode broj od nekoliko hiljada pa do nekoliko desetina hiljada. Poslednjih decenija rehabilitacija navedenih lica je veoma aktuelna $u$ Srbiji tako da je i donošenje Zakona o rehabilitaciji 2006. izazvalo interesovanje ne samo naučne i stručne već i najšire javnosti. O Zakonu o rehabilitaciji iz 2006. raspravljalo se i pisalo u stručnoj i najširoj javnosti, ali tek po njegovom donošenju. ${ }^{3}$ Zakon o rehabilitaciji iz 2006. jedan je od najkraćih zakona koji je donet $u$ Srbiji uopšte i $u$ delu stručne javnosti bio je podvrgnut kritici zbog nepotpunosti u pogledu postupka. ${ }^{4}$

Novi Zakon o rehabilitaciji donet je 5. decembra $2011 .{ }^{5} \mathrm{U}$ odnosu na Zakon o rehabilitaciji iz 2006, ovaj zakon je obimniji, sadrži 33 člana, potpuniji je, precizniji u pogledu materijalnog prava i postupka rehabilitacije. Zakon navodi nove precizne odredbe koje se odnose na: rehabilitaciju i ograničenje prava na vraćanje oduzete imovine i obeštećenje, rehabilitaciju i pravne posledice rehabilitacije, vrste rehabilitacije, nadležnost suda, istražno načelo, pravila postupka, primenu Zakona o vanparničnom postupku, žalbu protiv rešenja o rehabilitaciji, prava rehabilitovanih lica.

Na osnovu Zakona o rehabilitaciji iz 2006. do sada su rehabilitovane poznate ličnosti koje je osudila komunistička vlast posle 1945. na osnovu tzv. revolucionarne pravde: akademik Slobodan Jovanović, književnik Dragiša Vasić, književnik Grigorije Božović, profesor dr Dragoljub Jovanović, glumica Žanka Stokić, slikar Branko Popović, književnik Živojin Pavlović, advokat Veljko Guberina, advokat Slobodan Subotić, akademik Dragoslav Mihailović, književnik Borislav Pekić, štampar dr Pavle Gregorić, komunista Andrija Hebrang, ministar Dvora Milan Antić i drugi. Sudovima u Srbiji podneto je nekoliko stotina zahteva za rehabilitaciju, ali sudski postupci se odvijaju veoma sporo. ${ }^{6}$ Razlozi sporosti u rešavanju pitanja rehabilitacije nisu nam poznati.

Najpoznatiji slučaj sudske rehabilitacije u Srbiji jeste rehabilitacija kneza Pavla Karađorđevića (1893-1976). Viši sud u Beogradu je 28. novembra 2011. doneo rešenje Reh. Br. 226/10 kojim se usvaja zahtev za rehabili-

\footnotetext{
${ }^{3}$ Službeni glasnik Republike Srbije, br. 33, 17. april 2006, 9.

${ }^{4}$ Vladimir V. Vodinelić, Zakon o o rehabilitaciji: tužna priča sa možda srećnim krajem, Hereticus, Vol. VI. (2008), No. II, Beograd 2008, 42-47.

${ }^{5}$ Službeni glasnik Republike Srbije, br. 92, 5. decembar 2011.

${ }^{6}$ Jedan od izuzetaka je Okružni sud u Šapcu koji je doneo najviše rešenja o rehabilitaciji u Srbiji. Videti: Gojko Lazarev, Zakon o rehabilitaciji - dve godine kasnije, Hereticus, Vol. VI, Beograd 2008, No. II, 71.
} 
taciju kneza Pavla Karađorđevića, gde se utvrđuje da je ništava Odluka Državne komisije za utvrđivanje zločina okupatora i njihovih pomagača $F$. Dr. 3572 od 17. septembra 1945, od dana njenog donošenja, kao i da su ništave sve pravne posledice navedene odluke, uključujući i kaznu konfiskacije imovine, a rehabilitovano lice knez Pavle Karađorđević se smatra neosuđivanim, na osnovu Zakona o rehabilitaciji od 17. aprila 2006. ${ }^{7}$ Zahtev za rehabilitaciju je podnela ćerka kneza Pavla princeza Jelisaveta Karađorđević 7. jula 2008. tadašnjem Okružnom sudu u Beogradu, a kasnije su podnete od strane punomoćnika dopune početkom 2011. Prvo ročište je održano 27. septembra 2011, a na drugom 28. novembra 2011, doneto je rešenje o usvajanju rehabilitacije.

Knez Pavle Karađorđević je bio prvi namesnik Kraljevine Jugoslavije posle ubistva kralja Aleksandra I Karađorđevića 1934. u Marselju. Dužnost namesnika vršio je u periodu od 1934. do 1941. odnosno do puča od 27. marta $1941,{ }^{8}$ kada je od strane pučista proteran sa celom porodicom prvo u Egipat, a zatim u Keniju gde je ostao do 1948. i nikada se više nije vratio u Jugoslaviju.

Potpisivanjem Trojnog pakta 25. marta 1941. u Beču, čiji su potpisnici bili predsednik jugoslovenske vlade Dragiša Cvetković i ministar inostranih poslova Jugoslavije Aleksandar Cincar-Marković, ${ }^{9}$ pučistička vlada generala Simovića proglasila je kneza Pavla Karađorđevića izdajnikom i on je pod britanskim pritiskom i naređenjem proteran u Keniju zajedno sa porodicom. Iako je knez Pavle bio poznat kao anglofil i prijatelj Engleske, u engleskom parlamentu je proglašen za kvislinga, optužen da je hteo da uzurpira krunu, da je lično fašista, da je ljubomoran na kralja Petra i da gaji lične ambicije. ${ }^{10}$

Pučistička vlada Dušana Simovića nije poništila Protokol o pristupanju Jugoslavije Trojnom paktu i vodila je uzdržanu politiku da bi izbegla rat. Za sve je, međutim, bilo kasno: Hitler je već bio doneo odluku o agresiji na Jugoslaviju koja je usledila 6. aprila 1941. Epilog te agresije i okupacije Jugoslavije od strane Nemačke, Italije, Bugarske i Mađarske je poznat: ogroman broj ljudskih žrtava (1,9 miliona), neviđena razaranja gradova, sela, privrede, infrastrukture kao i masovni ratni zločini.

${ }^{7}$ Zakon o rehabilitaciji, Službeni glasnik Republike Srbije, 17. april 2006, 9.

${ }^{8}$ B. Petranović, N. Žutić, 27. mart 1941. tematska zbirka dokumenta, Beograd 1990; F. Čulinović, Dvadeset sedmi mart, Zagreb 1965; Nikola Milovanović, Vojni puč i 27. mart 1941, Beograd 1981; Ž. L. Knežević, 27. mart 1941, Njujork 1979; H. Jakob, Jugoslavija u krizi 1934-1941, Rijeka 1972.

${ }^{9}$ Protokol o pristupanju Kraljevine Jugoslavije Trojnom paktu, Beč, 25. mart 1941, Balkanski ugovorni odnosi 1876-1996, tom II (1919-1945), Beograd 1998, 470-473.

${ }^{10}$ N. Balfur, Knez Pavle Karađorđević, zbornik radova, Beograd 2003, 25. 
Godine 1945. komunistička vlast u Jugoslaviji se samo nadovezala na optužbe koje su knezu Pavlu Karađorđeviću izrekli pučisti i Englezi, pa ga je Državna komisija za utvrđivanje zločina okupatora i njihovih pomagača proglasila za ratnog zločinca 15. septembra 1945. i konfiskovala mu imovinu. ${ }^{11}$ Predsedništvo Prezidijuma Narodne skupštine Federativne Narodne Republike Jugoslavije (FNRJ) donelo je 8. marta 1947. Odluku kojom se oduzima državljanstvo FNRJ i konfiskuje celokupna imovina: Petru Aleksandra Karađorđevića, Aleksandru Petra Karađorđevića, Tomislavu Aleksandra Karađorđevića, Andreju Aleksandra Karađorđevića, Mariji Aleksandra Karađorđevića, Pavlu Arsena Karađorđevića, Olgi Pavla Karađorđevića, Aleksandru Pavla Karađorđevića, Nikoli Pavla Karađorđevića i Jelisaveti Pavla Karađorđevića. ${ }^{12}$ Navedenom Odlukom Državne komisije za utvrđivanje zločina okupatora i njihovih pomagača F. Broj 3572. u kratkom opisu i kvalifikaciji zločina navodi se: izdaja naroda, gaženje Ustava, sabotaža naoružanja i pripreme zemlje za rat, razbijanje jedinstva naroda Jugoslavije i priprema agresivnog rata. Pored kratkih opisa i kvalifikacija zločina u Odluci se dalje navodi: Tako je on kroz to vreme izvršio teške zločine: 1. Gaženje Ustava i uzurpiranje kraljevske vlasti, 2. Sabotažu priprema naroda i zemlje za rat i odbranu, 3. Učestvovanje u stvaranju pete kolone u državi uopšte, a u vojsci i diplomatiji napose, 4. Rasturanje Male Antante i otuđenje Jugoslavije od zemalja demokratije, većinom njenih dotadanjih saveznika, 5. Priprema i potpis pakta kojim je 25. marta 1941. u Beču Jugoslaviju predao na milost i nemilost fašističkoj Nemačkoj.

Smatramo da navedena Odluka Državne komisije za utvrđivanje zločina okupatora i njihovih pomagača protivzakonita sa pravnog i činjeničnog aspekta, jer se radi o isključivo političkoj odluci, a ne odluci koja je zasnovana na zakonu. Naime, Državna komisija za utvrđivanje zločina okupatora i njihovih pomagača je upravni organ koji radi na osnovu administrativnog prava i koja ima striktno određenu nadležnost. Zadatak te komisije jeste da prikuplja prijave o izvršenim ratnim zločinima okupatora i njihovih pomagača, sastavlja zapisnike o saslušanjima osumnjičenih lica, zapisnike o oštećenim licima i svedocima, zapisnike o uviđajima na licu mesta, o iskopavanju masovnih grobnica i pojedinačnih grobova, da utvrđuje činjenice koje će poslužiti za pronalaženje i privođenje izvršioca kao i dokaze o izvršenim ratnim zločinima, koje će dostaviti nadležnom Javnom tužiocu ili sudu. Odluke koje je donosila Komisija bile su po pravilu kratke i sažete, pružajući samo prima facie dokaze za nadležne organe gonjenja za dalje

${ }^{11}$ Državna komisija za utvrđivanje zločina okupatora i njihovih pomagača, Odluka o utvrđivanju zločina okupatora i njihovih pomagača F. Broj 3572 od 17. septembra 1945.

${ }^{12}$ Odluka U. Broj 392 od 8. marta 1947. 
pokretanje krivičnog postupka. ${ }^{13}$ Stoga, Državna komisija za utvrđivanje zločina okupatora i njihovih pomagača nije sud, niti je dobila zadatak da vrši direktne funkcije optuživanja, suđenja i kažnjavanja. Imajući u vidu navedeno ova Komisija nije mogla da proglasi kneza Pavla Karađorđevića za ratnog zločinca, jer sud je jedini državni organ koji je nadležan da sudi za izvršene ratne zločine. Nijedan jugoslovenski sud, međutim, nikada nije sudio knezu Pavlu Karađorđeviću za ratne zločine.

Razmotrićemo svaku kvalifikaciji navedenih zločina. Pod jedan navodi se izdaja naroda, iako se u tom delu ne određuje u čemu se konkretno sastojala izdaja naroda. Nacionalni komitet oslobođenja Jugoslavije (NKOJ) pod brojem 42 od 11. januara 1945. dostavlja Odluku br. 42 o proglašenju Pavla Karađorđevića ratnim zločincem kao i o konfiskovanju njegove imovine Povereništvu za pravosuđe, drugu Frolu, da se stave primedbe i eventualne dopune. U obrazloženom predlogu NKOJ-a, Predsedništvo AVNOJ-a donosi odluku pa se u članu 1 navodi: „Pavle Karađorđević, sin Arsena Karađorđevića, oglašuje se ratnim zločincem i narodnim izdajnikom i sva njegova imovina, bez obzira gde se nalazila, konfiskuje se u korist države“ ${ }^{14}$ Povereništvo pravosuđa 22 . januara 1945 . daje svoje mišljenje 0 ovom predlogu. ${ }^{15} \mathrm{U}$ delu pod brojem I, u vezi sa krivičnim delom izdaje, navodi se sledeće: „Postupci Pavla Karađorđevića, izneti u izveštaju Državne komisije za utvrđivanje zločina okupatora i njegovih pomagača, ne bi se mogli smatrati kao izvršenje dela izdaje po krivičnom zakonu. Jedini propis koji bi dolazio u obzir bio bi čl. 103. K. Z. koji glasi: Ko povereni mu državni posao sa kakvom stranom vladom ili njenim opunomoćenikom izvrši na štetu Kraljevine Jugoslavije kazniće se robijom. Ako je delo učinjeno iz nehata, učinilac da se kazni zatvorom."

Radnje kneza Pavla Karađorđevića teško se mogu podvesti i pod ovaj propis, jer su svi njegovi postupci, a naročito pristupanje Trojnom paktu ozakonjeni, te bi se mogao istaći pravnički jak prigovor da se ne može smatrati kako su postupci Pavla Karađorđevića išli na štetu Kraljevine Jugoslavije kada su oni bili odobreni zakonom. U pogledu ovog propisa istaknuto je i ranije da će teško doći do primene, pošto su poslovi sa stranim državama zavisni od ratifikacije. U Krivičnom zakonu ne treba tražiti osnov za oglašenje Pavla Karađorđevića izdajnikom, a još manje ratnim zlo-

${ }^{13}$ A. Vajs, Rad Komisije za utvrđivanje zločina okupatora i njihovih pomagača, Anali Pravnog fakulteta u Beogradu, br. 4, Beograd 1961, 388-395.

${ }^{14}$ Original pisma Nacionalnog komiteta oslobođenja Jugoslavije - Potpredsedništvo i obrazloženi predlog NKJ Br. 42. od 11. januara 1945. nalazi se u Arhivu Jugoslavije (AJ) u Beogradu. nalazi se u AJ.

${ }^{15}$ Original mišljenja Nacionalnog komiteta Jugoslavije - Povereništvo pravosuđa 
čincem, pošto takav naziv za izvršioca krivičnog dela nije ni postojao. Mišljenje Povereništva pravosuđa u delu pod brojem I, kao i obrazloženje, sa pravnog aspekta su sasvim prihvatljivi, jer se argumentovano odbacuje predlog o proglašenju Pavla Karađorđevića za izdajnika, gde se uz ostalo u prvom planu predloga navodi izdaja naroda.

Pod brojem II se navodi: „Dela Pavla Karađorđevića, prema tome kao lica koje je pobeglo iz zemlje pre okupacije, ne bi mogla da budu predmet izviđanja pred Komisijom za utvrđivanje zločina okupatora i njihovih pomagača“. Veoma jasno i pravno argumentovano - da bi neko bio proglašen za ratnog zločinca morao je da bude fizički prisutan u Jugoslaviji od 1941. do 1945. Knez Pavle Karađorđević nije pobegao iz Jugoslavije nego ga je pučistička vlada 27. marta 1941. uhapsila i sa porodicom proterala prvo u Grčku, zatim u Egipat i na kraju u Keniju i Južnoafričku Republiku, gde su ostali sve do 1948, kada im je odobreno da mogu da se nastane u Francuskoj.

Stoga ni po kojem pravnom osnovu knez Pavle Karađorđević nije mogao da bude proglašen za ratnog zločinca iz osnovnog razloga što od 28. marta 1941. pa sve do 1948. nije bio u Jugoslaviji, tako da nije mogao fizički da izvrši bilo kakav ratni zločin. Zatim, knez Pavle bio je sa svojom porodicom sve vreme u Keniji, interniran i izolovan od strane engleske vojske, bez bilo kakvih kontakata sa spoljnim svetom, pogotovo bez komunikacije sa vojnim organizacijama u Jugoslaviji za vreme okupacije od 1941. do 1945. da bi izdavao naređenja i slično, što bi se moglo okvalifikovati kao ratni zločin.

Pod brojem III daje se mišljenje vezano za definiciju „ratnog zločinca“ i „narodnog neprijatelja" koji su predviđeni u članovima 13 i 14 Uredbe o vojnim sudovima, pa se navodi: „Iz ovih propisa jasno se vidi, da su pod pojmom ratnog zločina i narodne izdaje takođe uzeti u prvom redu zločini izdaje za vreme okupacije, te se ni pod ove propise ne može podvesti umišljajni izdajnički rad Pavla Karađorđevića“.

Pod brojem IV daje se mišljenje o odluci AVNOJ-a od novembra 1944. o prelazu u državnu svojinu neprijateljske imovine i o državnoj upravi nad imovinom neprisutnih lica, kojom se predviđalo da imovina lica koja nisu prisutna pređe pod državnu upravu. Navodi se sledeće: „Po ovom osnovu ne bi se mogla izvršiti konfiskacija imovine Pavla Karađorđevića, jer je u pitanju samo „imovina odsutnih lica koja su u toku okupacije nasilno odvedena ili su sami izbegli“ (čl. 2).

Pod brojem $\mathrm{V}$ navodi se nemogućnost da se po propisima bivše Jugoslavije i propisima koji su doneti u toku Narodnooslobodilačke borbe rad Pavla Karađorđevića proglasi kao zločinački i izdajnički i da mu se konfiskuje imovina i predlažu se dve mogućnosti na koji način da se knez proglasi zločincem i izdajnikom. Prvo, doneti odluku opšte naravi u kojoj bi se 
dala definicija narodnog izdajnika i ratnog zločinca, no koja ne bi bila vezana za vreme okupacije. Na osnovu takve odluke Pavle Karađorđević bi bio proglašen ratnim zločincem i narodnim izdajnikom. Drugo, aktom zakonodavne vlasti posebno proglasiti Pavla Karađorđevića ratnim zločincem i narodnim izdajnikom na osnovu podataka i materijala koji bi trebalo združiti uz original odluke. Konfiskacija imovine bila bi samo posledica proglašenja Pavla Karađorđevića ratnim zločincem. Ako bi se donosila posebna odluka AVNOJ-a o proglašenju Pavla Karađorđevića ratnim zločincem možda ne bi bilo potrebno da se u toj odluci bilo šta govori o konfiskaciji, jer ako se on proglasi ratnim zločincem, onda osnov za konfiskaciju već samim tim postoji i to na osnovu čl. 1 t. 3 Odluke o prelazu u državnu imovinu neprijateljske imovine i o državnoj upravi nad imovinom neprisutnih lica.

Očigledno je da je Povereništvo pravosuđa u delu pod brojem V gde se daje predlog za proglašenje Pavla Karađorđevića za ratnog zločinca i narodnog izdajnika, zapalo u potpunu pravnu kontradikciju. Jer, Povereništvo prvo navodi nemogućnost da se propisima Kraljevine Jugoslavije i propisima koji su doneti u toku Narodnooslobodilačke borbe rad Pavla Karađorđevića proglasi zločinačkim i izdajničkim, a zatim predlaže dve mogućnosti da bi se ostvarila forma njegovog proglašenja za ratnog zločinca i narodnog izdajnika i konfiskovala njegova imovina, kao i donošenje posebne odluke AVNOJ-a o proglašenju za ratnog zločinca. Ovi predlozi su lišeni svake pravne osnove već predstavljaju isključivo političku konstrukciju čiji je cilj da se knez Pavle Karađorđević protivpravno proglasi za ratnog zločinca i narodnog neprijatelja.

U kratkom opisu i kvalifikaciji zločina navodi se i gaženje Ustava. Pavle Karađorđević, kako se obrazlaže, pogazio je Ustav na taj način što je celokupnu vlast uzeo u svoje ruke kao neograničen gospodar ignorišući narodno predstavništvo. Doneti su protivustavni zakoni o neravnopravnosti građana, a spoljna i unutrašnja politika su vođene po njegovom nahođenju, bez obzira na interese zemlje. Knez Pavle je razvijao mržnju jednog naroda protiv drugog, u spoljnoj politici neodoljivom mržnjom prema SSSR-u napustio je dotadašnje saveze i naslon na demokratske zemlje i tajno uključio Jugoslaviju privredno i politički u potpunu zavisnost sila Osovine i 1941. zaključio Trojni pakt, pošto je prethodno i sistematski sprovodio sabotažu naoružanja i pripremao zemlju za kapitulaciju.

Neosnovano je tvrđenje da je Pavle Karađorđević pogazio Ustav i bio neograničeni gospodar, ignorišući narodno predstavništvo. Postojala je Narodna skupština koja je donosila sve važnije odluke kako u unutrašnjoj tako i u spoljnoj politici, koje je izvršavala vlada. Knez Pavle nije donosio nikakve odluke vezane za unutrašnju i spoljnu politiku. U predvečerje Dru- 
gog svetskog rata, 1938-1939. godine nastojao je da Jugoslavija zadrži neutralan položaj, jer je bilo očigledno da Velika Britanija i Francuska objektivno ne mogu, a i ne žele da vojno i finansijski pomognu Jugoslaviju. Postojao je pritisak Velike Britanije i Francuske, kao i SAD da Jugoslavija priđe tim zemljama bez davanja vojne pomoći i određenih garancija. S druge strane, Nemačka i Italija su vršile veliki pritisak da Jugoslavija pristupi Trojnom paktu. Poznat je stav Ministarstva vojnog i Generalštaba Kraljevine da je jugoslovenska vojska veoma slabo naoružana, nespremna za rat i da se ne može odupreti agresiji Nemačke. Francuska - jedna od vojno najjačih država u Evropi - već je bila kapitulira za petnaestak dana pred agresijom nacističke Nemačke. Jugoslovenska vojska nije imala nikakve šanse da se sa slabim i zastarelim naoružanjem odupre agresiji Nemačke. To je potvrdio i Aprilski rat 1941. u kojem su nacistička Nemačka i fašistička Italija za desetak dana slomili otpor jugoslovenske vojske.

U odnosu na spoljnu politiku Kraljevine Jugoslavije prema SSSR-u tvrdnja da je „Namesnik Pavle zadojen neodoljivom mržnjom prema SSSR“ je neistinita, potpuno neosnovana i lišena svakog pravnog osnova. Kraljevina Jugoslavija od svog nastanka 1918. nije htela da prizna SSSR niti da uspostavi diplomatske ili bilo kakve druge odnose sa ovom državom. ${ }^{16} \mathrm{U}$ to vreme knez Pavle Karađorđević nije imao nikakvu političku funkciju ili vlast, niti se bavio politikom već su o tome odlučivali Narodna skupština, vladajuće političke partije, jugoslovenska vlada i kralj Aleksandar. Knez Pavle postaje namesnik tek posle ubistva kralja Aleksandra krajem 1934. u Marseju. Činjenica je da je knez nastojao da normalizuje odnose sa SSSRom pa su dok je bio namesnik diplomatski odnosi uspostavljeni 31. maja 1940, ${ }^{17}$ a 5. aprila 1941. u Moskvi je zaključen Ugovor o prijateljstvu i nenapadanju između Kraljevine Jugoslavije i Saveza Sovjetskih Socijalističkih Republika. ${ }^{18}$ Dalje se navodi: Sabotaža naoružanja i priprema zemlje za rat. Nikakvi dokazi ni za ovu tvrdnju nisu navedeni.

Imajući u vidu navedeno želimo da istaknemo sledeće: da je jugoslovenska vojska bila veoma slabo naoružana i objektivno nije mogla da pruži

${ }^{16}$ V. Vinaver, Jugoslovensko-sovjetski odnosi 1919-1929. Pitanje priznanja SSSR $i$ uspostavljanje diplomatskih odnosa, Istorija XX veka, Beograd 1965, VII, 492.

17 B. Petranović, Uspostavljanje jugoslovensko-sovjetskih diplomatskih odnosa 1940, Zbornik Matice Srpske za istoriju, br. 46, Novi Sad 1992, 87; Miladin Milošević, Uspostavljanje diplomatskih odnosa između Kraljevine Jugoslavije i SSSR-a 1940, Istorijski zapisi, br. 3-4, Podgorica 2007, 99; Vuk Vinaver, Spoljnopolitička pozadina uspostavljanja jugoslovenskosovjetskih diplomatskih odnosa 1940. godine, Zbornik Matice Srpske za društvene nauke, br. 45, Novi Sad 1966, 5.

${ }^{18}$ Ugovor o prijateljstvu i nenapadanju izmedu Kraljevine Jugoslavije i Saveza Sovjetskih Socijalističkih Republika, Moskva, 5. aprila 1941, Balkanski ugovorni odnosi 1876-1996, tom II (1919-1945.), Beograd 1998, 478; Vuk Vinaver, Jugoslovensko-sovjetski pakt od aprila 1941. godine, Istorijski glasnik, br. 1, Beograd 1973, 7. 
ozbiljniji otpor Nemačkoj i Italiji koje su se otvoreno spremale za agresiju. Do tada je Jugoslavija prvenstveno kupovala oružje od Čehoslovačke, a manji deo od Francuske, Nemačke, Belgije i Italije. Pošto je Drugi svetski rat počeo 1. septembra 1939, Čehoslovačka više nije postojala, Francuska, Nemačka, Engleska i Italija su bile u ratu, tako da se od tih država nije moglo kupovati oružje. Sovjetski Savez nije prodavao oružje jer se i sam naoružavao, pošto je uvideo da može biti napadnut. Tada nisu postojali diplomatski odnosi sa Sovjetskim Savezom, tako da nije dolazila u obzir mogućnost bili kakvog pregovaranja i kupovine oružja. Knez Pavle Karađorđević je u maju 1939. pokušao da obezbedi proširenje trgovinskih odnosa i isporuke oružja od Engleske, ali do toga nije došlo. Ni poseta kneza Pavla neposredno posle toga nije donela nikakve rezultate. Englezi su spominjali nekakve besmislene političke kredite i tokom posete isticali važnost kneza Pavla kao prijatelja od poverenja. ${ }^{19}$ U nastojanju da od SAD kupi oružje knez Pavle Karađorđević je maja 1939. lično ambasadoru SAD u Parizu Bulitu podneo zahtev za kupovinu oružja, ali od tog zahteva nije bilo ništa. $^{20}$

Jedina mogućnost bila je kupovina oružja neposredno od SAD, koje su tada bile neutralne, ali su imale oružja za prodaju. Knez Pavle Karađorđević decembra 1939. šalje u SAD dr Davida Albalu, ${ }^{21}$ u specijalnu poverljivu misiju radi dobijanja kredita za kupovinu oružja za jugoslovensku vojsku. Albala je izabran kao knežev prijatelj, a i stoga što je 1917. bio član Srpske delegacije u SAD koju je predvodio dr Milenko Vesnić. Tada je Albala obezbedio ratni zajam za Srbiju u visini od milion dolara. Srpski poslanik u Vašingtonu Ljuba Mihailović, i pored svih zalaganja, nije uspeo da dobije taj zajam već je to učinio dr Albala. Knez Pavle je računao da će preko jevrejskih veza koje je Albala imao u finansijskim krugovima SAD još iz 1917-1918. obezbediti zajam za kupovinu oružja.

Misija Davida Albale je bila tajna kako za nju ne bi saznale Nemačka i Italija, kao i deo pronemački orijentisane opozicije u Jugoslaviji (Stojadinović, Ljotić, Maček, Spaho, Krek i drugi). Za misiju nije znao ni ambasador Jugoslavije u Vašingtonu Konstantin Fotić. Dr David Albala je trebalo

${ }^{19}$ S. Trifković, Pritisak Velike Britanije i Sjedinjenih Američkih Država, Beograd 2003, Zbornik radova okruglog stola „27. mart: Knez Pavle u vihorima evropske politike“, 101-102.

${ }^{20}$ Isto, 102-103.

${ }^{21}$ Dr David Albala (1886-1942), lekar iz Beograda, pisac i politički radnik. - Paulina Albala, David Albala kao jevrejski nacionalni radnik, Jevrejski almanah 1957-1958, Beograd 1958, 94; M. Koljanin, Druga misija Dr Davida Albale u Sjedinjenim Američkim Državama 1939-1942. godine, Jevrejski istorijski muzej - Beograd, Zbornik 8, Beograd 2003, 7; P. Lebl Albala, Vidov život: Biografija dr Davida Albale, Beograd 2008. 
da u SAD obezbedi kredit za kupovinu odbrambenog oružja (brzi aeroplani, protiv avionski i protiv tenkovski topovi). ${ }^{22}$

Za ovu poverljivu misiju Davida Albale u Sjedinjenim Američkim Državama nije znala ni domaća naučna, stručna i šira javnost. Tek je objavljivanjem studije Milana Koljanina, najboljeg poznavaoca života i rada Davida Albale, Druga misija dr Davida Albale u Sjedinjenim Američkim Državama 1939-1942, ${ }^{23}$ detaljno opisana njegova druga misija u SAD.

Svakako da tajna i poverljiva misija Davida Albale u SAD ukazuje na sasvim drugu sliku o knezu Pavlu Karađorđeviću od one koja je vladala sve do devedesetih godina prošlog veka. Prvo su Englezi odmah po potpisivanju Trojnog pakta potpuno neosnovano proglasili kneza Pavla za izdajnika Jugoslavije, nemačkog čoveka, narodnog neprijatelja, ratnog zločinca, kvislinga, uzurpatora krune i čoveka ljubomornog na kralja Petra. ${ }^{24}$ Pučistička vlada je preuzela engleske kvalifikacije kneza Pavla kao izdajnika i narodnog neprijatelja. Komunistička vlast je 1945. prihvatila tu ocenu, s tim što je donela i Odluku o proglašenju kneza Pavla Karađorđevića za ratnog zločinca i o konfiskaciji njegove celokupne imovine.

Knez Pavle Karađorđević, prema tome, nije sprovodio nikakvu sabotažu naoružanja i pripreme naroda i zemlje za rat i odbranu. Nastojao je, naprotiv, da dobijanjem zajma od Engleske i SAD nabavi oružje za odbranu Jugoslavije. Svakako da „izdajnik, nemački čovek, narodni neprijatelj, kvisling" ne bi poslao u tajnu misiju dr Davida Albalu radi kupovine oružja za odbranu Jugoslavije. Knez Pavle je važio kao anglofil, a ne kao simpatizer Nemačke i Italije, što je opšte poznata stvar. Nastojao je da Jugoslavija ostane neutralna u svetskom ratu koji je već bio počeo.

Pod brojem 3 navodi se Učestvovanje u stvaranju pete kolone u državi uopšte, a u vojsci i diplomatiji napose. Nikakvi dokazi za ove tvrdnje se ne prilažu. Knez Pavle Karađorđević nije bio ni na koji način povezan sa stvaranjem pete kolone $\mathrm{u}$ državi uopšte, a pogotovo u vojsci i diplomatiji. Takozvanu petu kolonu u vojsci stvarali su: nemački obaveštajci i nemačka nacionalna manjina u Jugoslaviji; mađarska italijanska, bugarska, albanska i muslimanska nacionalna manjina; pripadnici ustaša u Hrvatskoj i Bosni i Hercegovini; belogardejci u Sloveniji i VMR u Makedoniji. Oni su odmah posle kapitulacije Jugoslavije osnovali kvislinške države - Nezavisnu Državu Hrvatsku (NDH) i Nedićevu Srbiju, kao i kvislinške vojne formacije.

${ }^{22}$ Dr David Albala - Specijalni delegat pri Jugoslovenskom Kraljevskom poslanstvu u Vašingtonu 1939-1942, priredio Đ. N. Lopičić, Beograd 2010, 24.

${ }^{23}$ Druga misija dr Davida Albale u Sjedinjenim Američkim Državama 1939-1942, Jevrejski istorijski muzej Beograd, Zbornik 8, studije, arhivska i memoarska građa, Beograd 2003, 7-77.

${ }^{24}$ N. Balfur, Knez Pavle Karađorđević, 24-26. 
Budući da su se uoči rata u Jugoslaviji u vojsku, policiju, diplomatiju i druge javne službe infiltrirali najviše nemački a nešto manje i italijanski špijuni, mnoge državne tajne i poverljivi poslovi veoma su brzo saopštavani Nemcima i Italijanima. Knez Pavle Karađorđević sa tim nije imao nikakve veze; najbolji dokaz je što je dr Davida Albalu poslao u tajnu misiju za koju niko osim njih dvojice nije znao, jer bi to veoma brzo bilo javljeno Nemcima.

Pod brojem 4 navodi se Rasturanje Male Antante i otudenje Jugoslavije od zemalja demokratije, većinom njenih dotadanjih saveznika. I ovde se ne daju nikakvi dokazi za ove tvrdnje. Knez Pavle nema nikakve veze sa rasturanjem Male Antante, koja je osnovana 1921. kao savez Jugoslavije, Čehoslovačke i Rumunije radi zaštite članica od restauracije Habzburške monarhije od strane Austrije i Mađarske. Poslednji sastanak ove organizacije održan je na Bledu 28. avgusta 1938. Posle nestanka Čehoslovačke 30. septembra 1938, Mala Antanta je prestala da postoji. Inače, Mala Antanta nije predstavljala značajnu političku i vojnu snagu tog vremena u Evropi. ${ }^{25}$

Pod brojem 5 navodi se Fašiziranje zemlje i njeno privredno i političko potčinjavanje Nemačkoj i Italiji. Konkretni dokazi o ovim tvrdnjama nisu dati. Knez Pavle Karađorđević nema nikakve veze sa fašiziranjem zemlje i njenim privrednim i političkim potčinjavanjem Nemačkoj i Italiji. U Kraljevini Jugoslaviji je bilo više političkih partija koje su simpatisale nacističku Nemačku i Italiju. Najbolji dokaz je taj što su odmah posle kapitulacije Jugoslavije njihovi simpatizeri osnovali svoje kvislinške države i zauzeli rukovodeća mesta u okupacionoj kvislinškoj vlasti. Nemačka i Italija su pre rata eksploatisali jugoslovensku privredu, ali to isto su u međuratnom periodu radili i „saveznici“ Jugoslavije, Engleska i Francuska.

Pod brojem 6 se navodi Priprema i potpis Pakta kojim je 25. marta 1941. u Beču Jugoslaviju predao na milost i nemilost fašističkoj Nemačkoj. Ovo je potpuno netačna tvrdnja. Knez Pavle Karađorđević je nastojao da Jugoslavija ostane neutralna u već započetom Drugom svetskom ratu. Pregovarao je sa Nemačkom i Italijom i težio tome da te pregovore odugovlači. Engleska i SAD su vršile veliki pritisak na Jugoslaviju da pristupi njihovom savezu, a ne da ostane neutralna. Pri tome nikakvu vojnu pomoć ni garancije nisu pružali. Jugoslavija se našla između dve vatre; pritisak Nemačke i Italije bio je veliki. Odluku o potpisivanju Trojnog pakta doneli su Jugoslovenska vlada i Krunski savet, a ne knez Pavle Karađorđević. Trojni pakt su 25. marta 1941. u Beču potpisali predsednik jugoslovenske vlade Dragiša Cvetković i ministar inostranih poslova Aleksandar Cincar-Marković, a ne knez Pavle Karađorđević koji nije ni prisustvovao tom činu. Protokol o pri-

${ }^{25}$ M. Vanku, Mala Antanta 1920-1938, Titovo Užice 1969; M. Vanku, Uloga velikih sila na razbijanju Male Antante, Balcanica VIII, Beograd 1977, 529. 
stupanju Trojnom paktu, kao i svi međudržavni ugovori, trebalo je da bude ratifikovan u Narodnoj skupštini Kraljevine Jugoslavije da bi stupio na pravnu snagu. Do toga nije došlo jer je 27. marta 1941. u vojnom puču zbačena vlada Dragiše Cvetkovića, a već 6. aprila 1941. Nemačka i Italija su napale Jugoslaviju. Ovaj puč su inicirali Englezi, i to je opšte poznata činjenica.

Trojni sporazum, bez obzira što je potpisan pod snažnim pritiskom Nemačke i Italije, nije sadržavao ništa štetno za nezavisnost Jugoslavije. U noti nemačkog ministra inostranih poslova Ribentropa jugoslovenskom premijeru Dragiši Cvetkoviću u Beču 25. marta 1941. pored ostalog se navodi: „Povodom današnjeg pristupanja Jugoslavije trojnom paktu, nemačka vlada potvrđuje svoju odluku da poštuje suverenitet i teritorijalni integritet Jugoslavije bez ikakvog ograničenja. Gospodine prvi ministre, povodom razgovora vođenih $u$ vezi pristupanja Jugoslavije trojnom paktu imam čast da vašoj ekselenciji ovim putem potvrdim u ime vlade Rajha da, u skladu sa sporazumom između vlada Sila Osovine i Kraljevske jugoslovenske vlade, vlada Sila Osovine neće tokom ovog rata od Jugoslavije tražiti da dozvoli transport trupa preko jugoslovenske države ili kroz njenu teritoriju." 26

Na osnovu navedene Odluke Državne komisije Demokratske Federativne Jugoslavije F broj 3572. od 17. septembra 1945. Predsedništvo Prezidijuma Narodne skupštine FNRJ od 8. marta 1947. pod brojem U. 392 donelo je odluku: „Oduzima se državljanstvo Federativne Narodne Republike Jugoslavije i konfiskuje celokupna imovina: Petru Aleksandra Karađorđevića, Aleksandru Petra Karađorđevića, Tomislavu Aleksandra Karađorđevića, Andreju Aleksandra Karađorđevića, Mariji Aleksandra Karađorđevića, Pavlu Arsena Karađorđevića, Olgi Pavla Karađorđevića, Aleksandru Pavla Karađorđevića, Nikoli Pavla Karađorđevića i Jelisaveti Pavla Karađorđevića, sada svi u inostranstvu“. ${ }^{27} \mathrm{Na}$ osnovu Odluke od 8. marta 1947. konfiskovana je celokupna nepokretna i pokretna imovina kneza Pavla Karađorđevića: dvorac Brdo kod Kranja u Sloveniji sa nameštajem i umetničkim slikama; vila sa nameštajem i umetničkim slikama u Užičkoj 1 u Beogradu; umetničke slike, biblioteka i nameštaj iz Belog dvora u Beogradu; celokupna kolekcija umetničkih slika iz Muzeja kneza Pavla Karađorđevića u Beogradu.

Tek 27. februara 2001. Zakonom o ukidanju Ukaza o oduzimanju državljanstva i imovine porodici Karađorđević od 8. marta 1947. u članu 1 vraćeno je državljanstvo porodici Karađorđević uključujući i kneza Pavla

${ }^{26}$ Balkanski ugovorni odnosi 1876-1996, Dvostrani i višestrani međunarodni ugovori i drugi diplomatski akti o državnim granicama, političkoj i vojnoj saradnji, verskim i etničkim manjinama, II. tom (1919-1945), priredio M. Stojković, Beograd 1998, 470-473.

${ }^{27}$ Službeni list FNRJ, br. 64, 1. avgust 1947 (original Odluke u AJ). 
Karađorđevića, Olgu Karađorđević, Aleksandra Karađorđevića, Nikolu Karađorđevića i Jelisavetu Karađorđević. U članu 2 navodi se da će uslovi za povraćaj konfiskovane imovine iz člana 1 ovog Zakona biti uređeni posebnim zakonom. ${ }^{28}$

Jugoslovenska istoriografija prihvatila je posle Drugog svetskog rata stav zvanične jugoslovenske politike da je knez Pavle Karađorđević ratni zločinac, izdajnik, narodni neprijatelj, ne upuštajući se u ozbiljnija istraživanja njegove ličnosti i politike. Takav stav je ostao nepromenjen sve do 1990, kada su započele slobodne rasprave o mnogim događajima iz novije i savremene istorije, pa i o knezu Pavlu. Objavljeno je nekoliko značajnih knjiga, članaka, rasprava, feljtona, osvrta i prikaza. ${ }^{29}$ Sve je to doprinelo da se otvori pitanje rehabilitacije kneza Pavla Karađorđevića i da se u najširoj javnosti promeni nepravedna, iskrivljena i tendenciozna slika o njemu koja je trajala od 1941. pa sve do devedesetih godina XX veka.

Knez Pavle Karađorđević nije mogao biti odgovoran za potpisivanje Trojnog pakta od 25. marta 1941, jer niti je bio lice koje je po Ustavu imalo prava odlučivanja, niti je taj dokument potpisao. Priprema, odlučivanje i potpisivanje spadali su u nadležnost jugoslovenske vlade čiji je predsednik bio Dragiša Cvetković. Odluka Državne komisije za utvrđivanje zločina okupatora i njihovih pomagača o proglašenju kneza Pavla Karađorđevića za ratnog zločinca F broj 3572 od 17. septembra 1945. bila je protivzakonita i politička odluka komunističke vlasti, lišena bilo kog pravnog osnova. Odlukom o rehabilitaciji kneza Pavla Karađorđevića otklonjena je nepravda ali, nažalost, knez Pavle to nije doživeo.

Rehabilitaciju kneza Pavla Karađorđevića prihvatili su i potvrdili zvanični državni organi, na taj način što je dozvoljen prenos posmrtnih ostataka kneza Pavla, kneginje Olge Karađorđević i kneževića Nikole Karađorđevića iz Lozane u Srbiju, gde su 6. oktobra 2012. uz najviše državne počasti sahranjeni u porodičnoj grobnici na Oplencu. Svečanoj sahrani prisustvovali su predsednik Republike Srbije Tomislav Nikolić i predstavnici Vlade Republike Srbije.

${ }^{28}$ Službeni list Savezne Republike Jugoslavije, br. 9, 2. mart 2001, 4.

${ }^{29}$ Navodimo samo neke knjige: Nil Balfur, Seli Mekej, Pavle Karađorđević jedna zakasnela biografija, Beograd 1990; Knez Pavle Karađorđević u vihorima evropske politike, Zbornik radova okruglog stola „27. mart 1941, Beograd 2003; Miodrag Janković, Knez Pavle od lepote do istine, Beograd 2004; Miodrag Janković, Veljko Lalić, Knez Pavle - Istina o 27. martu, Beograd 2007; David Albala - Specijalni delegat pri Jugoslovenskom Kraljevskom poslanstvu u Vašingtonu 1939-1942, priredio Đorđe N. Lopičić, Beograd 2010. 
Jelena Đ. Lopičić Jančić

THE SERBIAN LAW OF THE REHABILITATION IN PRACTICE

\section{Summary}

This article deals with issues of rehabilitation in Serbian Law. It was discussed the Law on Rehabilitation of Republic of Serbia from 2006. and 2011. In the article was given the case of the known people who were rehabilitated under this Act. In the Decision about rehabilitation is determined that the decisions of the State bodies and Courts of that time were abolished and all the legal consequences of those decisions were quashed. Special attention has been given to the rehabilitation proceedings of Prince Pavle Karadjordjević. In this case the Higher Court in Belgrade issued a Decision that rehabilitated Prince Pavle Karadjordjević, a former regent of the Kingdom of Yugoslavia and found that the Decision of the State Commission for Establishing the Crimes of the occupiers and their Collaborators where Prince Pavle Karadjordjević was declared a war criminal is null and void. On the basis of that Decision on the rehabilitation, the State issued a Decision to transfer the remains of Prince Pavle Karadjordjević, his wife Princes Olga and son Prince Nikola from Lausanne, Switzerland to Serbia. The funeral was conducted with the highest State honors on 6 October 2012 in the family tomb in Oplenac. 